\title{
Det problembaserede undervisningsdesign Fra ProPrak, til teori, til gruppearbejde
}

\author{
Mads Hovgaard, videnskabelig assistent, Enheden for Uddannelsesudvikling (Det \\ Sundhedsvidenskabelig Fakultet); Institut for Idrat og Biomekanik, Syddansk Universitet
}

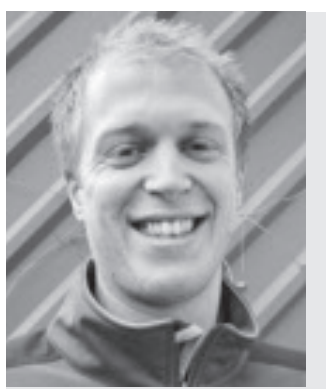

Mads Hovgaard er cand.scient. i Idræt og Sundhed, hvor specialeundersøgelsen (2009) indeholdt et casestudie af og interventionsstudie i et integreret metodisk undervisningsforløb og problembaseret projektarbejde på en uddannelsesinstitution. Mads Hovgaard arbejder med uddannelsesudvikling og kompetenceudvikling i relation til bacheloruddannelsen i Idræt og Sundhed, Syddansk Universitet, og dennes undervisere. Desuden underviser Mads Hovgaard på uddannelsen inden for fagområderne problembaseret læring, didaktik, aktivitetsudvikling og undersøgelsesplanlægning og opgaveskrivning; og har i mange år beskæftiget sig med studieteknik og peer assistant learning i forbindelse med fakultetets faglige tutorordning.

\section{Reviewet artikel}

Artiklen beskriver, begrunder og eksemplificerer det problembaserede undervisningsdesign 'Fra ProPrak, til teori til gruppearbejde', som gennemgående blev anvendt $i$ et problembaseret og metodisk funderet undervisningsforløb på Syddansk Universitets idrcetsuddannelse. Indholdet, opbygningen og undervisningsformerne $i$ forløbet tog direkte afsat $i$ det problembaserede fagområdes teori og metoder, således at undervisningsdesignet direkte havde integreret, hvad de studerende skulle stimuleres til at loere $i$ henhold til studieordningens kompetencemål. Artiklen har til hensigt at inspirere universitetsundervisere til, hvordan god undervisning kan udvikles, tilrettelagges og realiseres $i$ praksis.

\section{Indledning}

Denne artikel omhandler et undervisningsforløb fra bacheloruddannelsen Idræet og Sundhed på Syddansk Universitet (SDU), som fandt sted i efteråret 2009. Undervisningsforløbet hed »Problembaseret læring - din læreproces og metodiske værktøjskasse« - en overskrift som er dækkende for forløbets faglige kerne. Jeg udviklede, planlagde, afviklede og evaluerede forløbet med fokus på, at ikke blot det konkrete indhold men også opbygning og undervisningsformer tog direkte afsæt $i$ fagområdets teori og metoder. Det grundproblem, jeg som underviser beskæftigede mig med, besad altså en fagdidaktisk karakter.

Formålet med artiklen er praktisk og anvendelsesorienteret, og jeg vil derfor beskrive og eksemplificere et undervisningsdesign med udgangspunkt i både en teoretisk begrundet ramme og egentlige praksiserfaringer fra undervisningsforløbets afvikling. Det er min hensigt, at artiklen er relevant for alle universitetsundervisere særligt dem med interesse for problembaseret læring da det problembaserede undervisningsdesign både 1) er et eksemplarisk eksempel på, hvordan et fagområdes centrale indhold og metoder direkte kan anvendes $i$ undervisningen, og 2) indeholder flere elementer, som relaterer sig til god undervisning generelt. ${ }^{1}$

Artiklen præsenterer indledningsvis baggrunden for undervisningsforløbet og de overordnende linjer i designet. Efterfølgende beskrives det didaktiske fokus $i$ den enkelte undervisningstime og et eksempel fra praksis. Afslutningsvis afrundes artiklen med en kort perspektivering og to generelle budskaber til artiklens målgruppe.

\section{PBL-tradition: Et tredje ben}

Grundprincipperne problembasering, studentercentrering og gruppebasering i problembaseret læring (PBL) (Pettersen 2001) udgør en central del af det pædagogiske fundament og læringssyn på SDU's idrætsuddannelse. Måden, hvorpå PBL indgår på uddannelsen, er fleksibel og kontekstafhængig (Macdonald 2001), hvorfor modulerne, som er meget forskellige, hvad angår antallet af fagområder, typen af fagområder i videnskabsteoretisk forstand og ECTS-point, har integreret grundprincipperne og konkrete PBL-værktøjer på forskellig vis.

Den type af PBL-model som anvendes, kobler sig ik- 
ke stringent til én bestemt tradition: Hverken til PBLuddannelsesmodellerne som praktiseres i eksempelvis Maastricht eller Linköping eller til projektarbejdemodellerne, som de kendes fra Aalborg Universitet eller Roskilde Universitet (Kolmos, 2008). ${ }^{2}$ Modellerne indeholder de samme grundlæggende læringsprincipper, men hvor PBL-uddannelsesmodellerne er bygget op i mindre tematiske blokke med professionsrettede cases og individuel eksamen, hvor den studerende arbejder selvstændigt og diskuterer cases i studiegrupper ud fra 7-trinsmodellen (se afsnittet Time 1: ProPrak), arbejder de studerende inden for projektarbejdemodellerne i grupper med forskellige længerevarende projekter, typisk med udgangspunkt i et mere komplekst og omfattende problem, hvor udviklingen af proceskompetencer desuden er eksplicit i fokus.

I lighed med førstnæunte tradition er uddannelsen på SDU bygget op i blokke, her 'kvarterer' af ni uger, som indeholder et eller flere moduler til samlet 15 ECTS-point. I hvert modul arbejder de studerende med en eller flere cases, hvis fælles træk er praksis-teori-integrerede, anvendelsesorienterede og professionsrettede. I lighed med projektpædagogikken fungerer arbejdsgruppen, her på fem personer, som en gennemgående læringsenhed, både i den skemalagte undervisning og som selvstyrende gruppe i den øvrige studietid. Udover arbejdet med casene er der tillige eksplicit fokus på at udvikle processuelle og samarbejdsrelaterede kompetencer. ${ }^{3}$ Gruppearbejde indgår desuden som en integreret del af flere afsluttende prøver (eksamener), både som skriftlige produkter og som egentlige idrætspraksisser. 7-trinsmodellen indgår ikke som et fast og påkrævet værktøj i problemløsningen af casene.

Med afsæt i Anette Kolmos' (2008) sammenligning af de to traditioner placerer jeg altså den aktuelle model på et tredje ben, som dels bygger på de fælles pædagogiske idealer og grundlæggende læringsprincipper, og dels i mikset form besidder elementer fra begge retninger.

\section{Rammen for undervisningsforløbet}

"Problembaseret læring - din læreproces og metodiske værktøjskasse« er et proces- og anvendelsesorienteret undervisningsforløb, som er placeret på uddannelsens første modul, »Mødet med Idræt og Sundhed«, hvor det udgør cirka 2 ud af 15 ECTS-point. Modulet har til formål at udvide den studerendes opfattelse af idræt og sundhed og indeholder en introduktion til uddannelsens tre vidensområder: Naturvidenskabelig, humanistisk-samfundsvidenskabelig og praktisk-pædagogisk. Udvalgte fagdele fra de tre vidensområder er knyttet til en problembaseret case, som er gennemgående i modulets sidste seks uger. Desuden besidder modulet et eksplicit procesfokus, da områderne gruppeprocesser og problembaseret læreproces indgår i modulets kompetencemål (Studieordningen 2008, side 17), hvilket Case 1 og Case 2 i de første tre uger lægger direkte op til. Se overblikket over modulet i kolonnerne til venstre i Tabel 1.

\begin{tabular}{|c|c|c|}
\hline Uge (Gang) & Cases i Modul I & Dagens tema i PBL-undervisningsforløbet \\
\hline $\mathbf{I}$ & $\begin{array}{l}\text { Case I: EGOn } \\
\text { - Bevægelse og refleksion i forskellige rum. } \\
\text { - Fokus: studentercentrering }\end{array}$ & Introduktion til fagområdet og forløbet \\
\hline 2 & \multirow{2}{*}{$\begin{array}{l}\text { Case 2: Klodshans } \\
\text { - Gruppedynamisk udfordring med natu- } \\
\text { ren som ramme. } \\
\text { - Fokus: gruppebasering }\end{array}$} & Samarbejdsaftalen \\
\hline 3 & & $\begin{array}{l}\text { Individet i gruppen } \\
\text { (om ligheder og forskelle mellem roller, typologier og } \\
\text { læringsstile) }\end{array}$ \\
\hline 4 & \multirow{6}{*}{$\begin{array}{l}\text { Case 3: Ilia } \\
\text { - Afvikle idrætsaktiviteter for en mindre } \\
\text { gruppe af } 45-60 \text {-årige i et udvalgt rum, } \\
\text { hvor der tages hensyn til målgruppens fy- } \\
\text { siologiske, psykologiske og sociale lærings- } \\
\text { forudsætninger. Herunder at tilegne sig } \\
\text { både fysiologisk, psykologisk og praktisk- } \\
\text { pædagogisk viden. } \\
\text { - Fokus: problembasering }\end{array}$} & $\begin{array}{l}\text { Faser i en problemløsningsproces } \\
\text { (ud fra en modificeret } 7 \text {-trinsmodel) }\end{array}$ \\
\hline 5 & & Styring af og vidensdeling i gruppemødet \\
\hline 6 & & Kontekstens betydning i en læreproces \\
\hline 7 & & $\begin{array}{l}\text { At stille spørgsmål \& } \\
\text { Den metodiske værktøjskasse (små værktøjer) }\end{array}$ \\
\hline 8 & & $\begin{array}{l}\text { Vidensdeling og refleksion over læreprocessen (studenter- } \\
\text { styret paneldebat) }\end{array}$ \\
\hline 9 & & Evaluering \\
\hline
\end{tabular}

Tabel I: Overblik over Modul I og Dagens tema i PBL-forløbet. 
Undervisningsforløbet relaterer sig til det overordnede kompetencemål »Redegøre for, anvende og reflektere over udvalgte principper i problembaseret læring som pædagogisk metode.« (Ibid.). Studieledelsen havde besluttet, at Roar C. Pettersens (2001) Problembaseret loring - for elever, studerende og larere skulle være primær litteratur blandt andet med den begrundelse, at den kunne anvendes som grundbog videre på studiet. Jeg var ansvarlig for årgangens fire hold á cirka 25 studerende gennem modulets ni uger. Hver uge havde jeg en undervisningsgang bestående af tre lektioner á 45 minutter i forlængelse af hinanden med hvert hold - på nær første og sidste gang, som var af kortere varighed. ${ }^{4}$ Jeg anvender termen 'time' som synonym med 'lektion' fremover $\mathrm{i}$ artiklen, da jeg har brugt denne term i undervisningsmaterialet.

\section{Udviklingen af det problembaserede undervisningsdesign}

Som beskrevet i indledningen var det centralt for mig at udvikle undervisningsforløbet med direkte afsæt i fagområdets teori og metoder. Det velvalgte faglige indhold og de hertil hørende metoder, samarbejdsformer og arbejdsgange er en central kvalitet i god undervisning (Fibæk Laursen 1999, s.11ff). Med udgangspunkt i Pettersen (2001) og undervisningslitteratur (se note 1) opstillede jeg fire principper, som til enhver tid skulle udgøre det didaktiske fundament $\mathrm{i}$ undervisningsforløbet: 1) Konstant hensynstagen til grundprincipperne problembasering, studentercentrering og gruppebasering, 2) en synlig kobling mellem teori og praksis, 3) et direkte afsæt til anvendelse af metodiske værktøjer uden for undervisningstimerne og på sigt i hele uddannelsesforløbet og 4) en sammenhæng til modulets opbygning, cases og øvrige fagområder.

De fire didaktiske principper er gensidigt afhængige og til dels indeholdt i hinanden, hvorfor de skal betragtes som en samlet helhed. Eksempelvis blev 'pro- blembasering' netop anvendt til at integrere praksis og teori (princip 2) og til at sætte fokus på faserne i de studerendes læreproces gennem modulets tre cases (princip 4). I helheden af de fire principper befinder forløbets faglige indhold sig. Til den enkelte undervisningsgang valgte jeg et dagens tema (se Tabel 1) på baggrund af både teori (her primært Pettersen), metodiske værktøjsbøger (eksempelvis Olsen \& Pedersen 2003) og empiri ${ }^{5}$.Tillige vægtede princip 4 også en del, da temaerne havde en direkte kobling til den case og det faglige indhold, som på samme tidspunkt foregik i modulet. Eksempler på dette er temaerne 'Samarbejdsaftalen' og 'Individet i gruppen' i modulets uge 2 og 3 , hvor der arbejdes med en kropspraktisk case med hovedformålet at udvikle gruppeprocesser; og temaerne 'Faser i en problemløsningsproces' og 'Styring af og vidensdeling i gruppemødet' i modulets uge 4 og 5 , hvor den længerevarende case med fokus på viden fra de tre vidensområder blev indledt.

På trods af sammenhængen i de fire didaktiske principper valgte jeg at udvikle et design for den enkelte undervisningsgang, hvor de respektive principper vægtede forskelligt på forskellige tidspunkter, da de studerende til sidst i forløbet både skulle kunne "redegøre for», "anvende« og »reflektere over« jævnfør det overordnede kompetencemål. Dette betød, at jeg i de enkelte timer arbejdede med forskellige kombinationer af mål, indhold, læreproces og vurdering (evaluering) ud fra en didaktisk relationstænkning - her beskrevet med Hilde Hiim og Else Hippes (1993) termer. Den første time var en problemløsningsproces i praksis, den anden time var teoretisk funderet, mens den tredje time var gruppearbejde med vejledning. De tre timer blev bundet sammen af dagens tema, således at specifikke faglige begreber, teorier eller metoder gik igen, om end de altså blev behandlet på forskellige måder. Se i Tabel 2 hvordan de fire didaktiske principper vægtede gennem de tre timer. I de kommende afsnit uddyber jeg hver af de tre timer.

\begin{tabular}{|l|l|c|c|c|}
\hline \multicolumn{2}{|r|}{ Undervisningstime: } & Time I & Time 2 & Time 3 \\
\hline \multicolumn{2}{|r|}{ Didaktiske principper: } & ProPrak & Teori & Gruppearbejde \\
\hline Ia & Problembasering & $\mathbf{X}$ & $\mathbf{x}$ \\
\hline Ib & Studentercentrering & $\mathbf{x}$ & $\mathbf{x}$ \\
\hline Ic & Gruppebasering & $\mathbf{x}$ & $\mathbf{X}$ \\
\hline 2 & Teori-praksis-kobling & Praksis & Teori & Praksis \\
\hline 3 & Afsæt til anvendelse & & $\mathbf{x}$ & $\mathbf{X}$ \\
\hline 4 & Sammenhæng med modulet & & $\mathbf{x}$ & $\mathbf{X}$ \\
\hline
\end{tabular}

Tabel 2:Vægtning af de didaktiske principper i hver af de tre undervisningstimer. »X« = Central vægtning, »x« = vægtet i nogen grad, »[intet] « = Ikke vægtet højt. 


\section{Time 1: ProPrak}

For at være tro mod det problembaserede princip valgte jeg, at hver enkelt undervisningsgang skulle starte med et mindre problemscenario med det formål at trigge de studerende til læring, ud fra forestillingen om at "...the starting point for learning should be a problem, a query, or a puzzle that the learner wishes to solve" (Boud, 1985). Her skulle den enkelte studerende som del af en gruppe aktivt løse et problem i praksis, hvis indhold tog direkte udgangspunkt i dagens centrale indhold.

Med inspiration fra Etienne Wengers (2007) 'socialt definerede kompetence' $i$ et praksisfællesskab og Kenneth Gergens (1994, s.59ff) tilskrivelse af sprogets funktion som meningsskaber i sociale kontekster valgte jeg at navngive dette mindre problemscenario ProPrak, hvilket er sammensat af ordene 'problem i praksis'. Min hensigt med denne selvkonstruerede term var, at de studerende i løbet af undervisningsforløbet skulle betragte de enkeltstående ProPrak'ker samlet på et metaniveau, som et gennemgående læringsfænomen i forløbet og i den forbindelse reflektere over og vurdere ProPrak's betydning i deres læreproces. ${ }^{6}$

Det var gennemgående i alle ProPrak'ker, at de studerende arbejdede i par eller grupper på tværs af de i modulet fungerende arbejdsgrupper. Formen og problemtypen var meget forskellig fra ProPrak til ProPrak, mens den afsatte tid typisk var 45 til 60 minutter.

Problemløsningsprocessen var underviserstyret for trin 1 og til dels trins 2's vedkommende ('Problembevidsthed og problemidentifikation', 'Problemdefinering'), da jeg i vid udstrækning havde designet ProPrak på forhånd, og herved havde udvalgt et specifikt problem (Pettersen 2001, s.68-90: 7-trinsmodellen). ${ }^{7}$ Problemløsningsfaserne 'Problemanalyse' og 'Konsekvensanalyse' (trin 3 og 4), som i kort udgave handler om, hvad en gruppe ved/kan og hvad gruppen ikke ved/kan, var indeholdt $\mathrm{i}$ forskellig grad i de enkelte ProPrak'ker. Trin 5 og 6, 'Planlægning og valg' og 'Gennemførsel', var hver gang i fokus og gennemgående var her, at faserne var deltagerstyrede. Opsummeringen på og evalueringen (trin 7) af ProPrak og de studerendes læreproces i første time fungerede som en glidende overgang til den anden times teoretiske perspektivering af dagens tema. 7-trinsmodellen blev ikke anvendt eksplicit under den enkelte ProPrak, men blev fra uge 4 og fremefter brugt som led i evalueringen - her specifikt til at analysere den aktuelle problemløsningsproces.

Et eksempel, taget fra Gang 6, omhandlede kontekstens betydning for læring, hvor ProPrak'ken var et lille eksperimentelt projekt med direkte afsæt i D. R. Godden og A. D. Baddeleys (1975) eksperiment med dykkere omhandlende indlæring og efterfølgende test $\mathrm{i}$ to forskellige fysiske miljøer - under vand og på land. Pettersen (2001, s.44ff) anvender det nævnte eksperiment til at argumentere for, at den problembasering der forgår under en uddannelse, skal være tæt relateret til den, som de studerende møder senere i livet under erhvervsudøvelse.

De studerende deltes ved lodtrækning $i$ to grupper, der begge skulle træne aktiviteten ' 3 på stribe' (Kryds og bolle) henholdsvis udendørs og indendørs. Fysiske parametre udgjorde forskellen mellem de to kontekster, da de studerende inde spillede siddende ved et bord og ude skulle løbe cirka 15 meter fra udgangspositionen til spillepladen. Efter endt træning konkurrerede grupperne mod hinanden, således at halvdelen af hver gruppe byttede omgivelser - som i dykkereksperimentet. Resultatet for konkurrencen ude og inde blev noteret ned og diskuteret i plenum i den efterfølgende time ved brug af teoretiske begreber og modeller som Jean Lave og Wengers (1991) 'situeret læring' og Knud Illeris' (2001) 'læringens spændingsfelt'.

\section{Time 2: Teori}

I den anden time af den enkelte undervisningsgang blev dagens tema anskuet fra en teoretisk vinkel. Til denne time havde jeg hver gang forberedt et teoretisk perspektiverende oplæg, som tog afsæt i ProPrak og dagens anbefalede litteratur. For at gøre de teoretiske og til tider abstrakte begreber mere tilgængelige for de studerende, gjorde jeg bevidst brug af metaforer, billedsprog og personligt oplevede eksempler, et narrativt element som Stewart Mennin og Ruy Souza (2009) anser som en vigtig del af god undervisning. Samtidig erfarede jeg, hvordan ProPrak medførte konkrete praksiserfaringer, som gav de studerende et motiverende udgangspunkt for efterfølgende at reflektere og tænke abstrakt (samspillet i David Kolbs (1984) The Learning Process).

Netop den individuelle motivation, ejerskabsfølelse og aktive deltagelse er en central parameter i problembaseret læring - knyttet til grundprincippet studentercentrering (Petterson 2001, s.36ff). Derfor forsøgte jeg også i Time 2 at tilgodese forskellige læringsstile og læringsstrategier hos de studerende med inspiration fra Ole Lauridsens (2007) udlægning og brug af Rita Dunn og Kenneth Dunns læringsstilprofiler og Building Excellence-modellen (Rundle \& Dunn). Denne didaktiske overvejelse gælder i øvrigt også for hele undervisningsdesignet, hvor de enkelte timer overordnet vurderet tilgodeser forskellige læringsstile.

Refleksionsspørgsmål til den enkelte studerende, korte samtaler med sidemanden og dialog i plenum var en integreret del af den teoretiske time. Disse miniseancer havde jeg lagt ind for at stimulere til deltageraktivitet og -interaktion (Biggs 2003, s.79ff). Når man, som jeg i dette tilfælde, arbejder med et didaktisk design med masser af deltageraktivitet, er det vigtigt nøje at udvælge undervisningens indhold, således at der gås i dybden med udvalgte og afgrænsede indholdsdele (Mennin \& Souza, 2009) $)^{8}$ - hvilket jeg forsøgte at efterleve på bedste vis. 


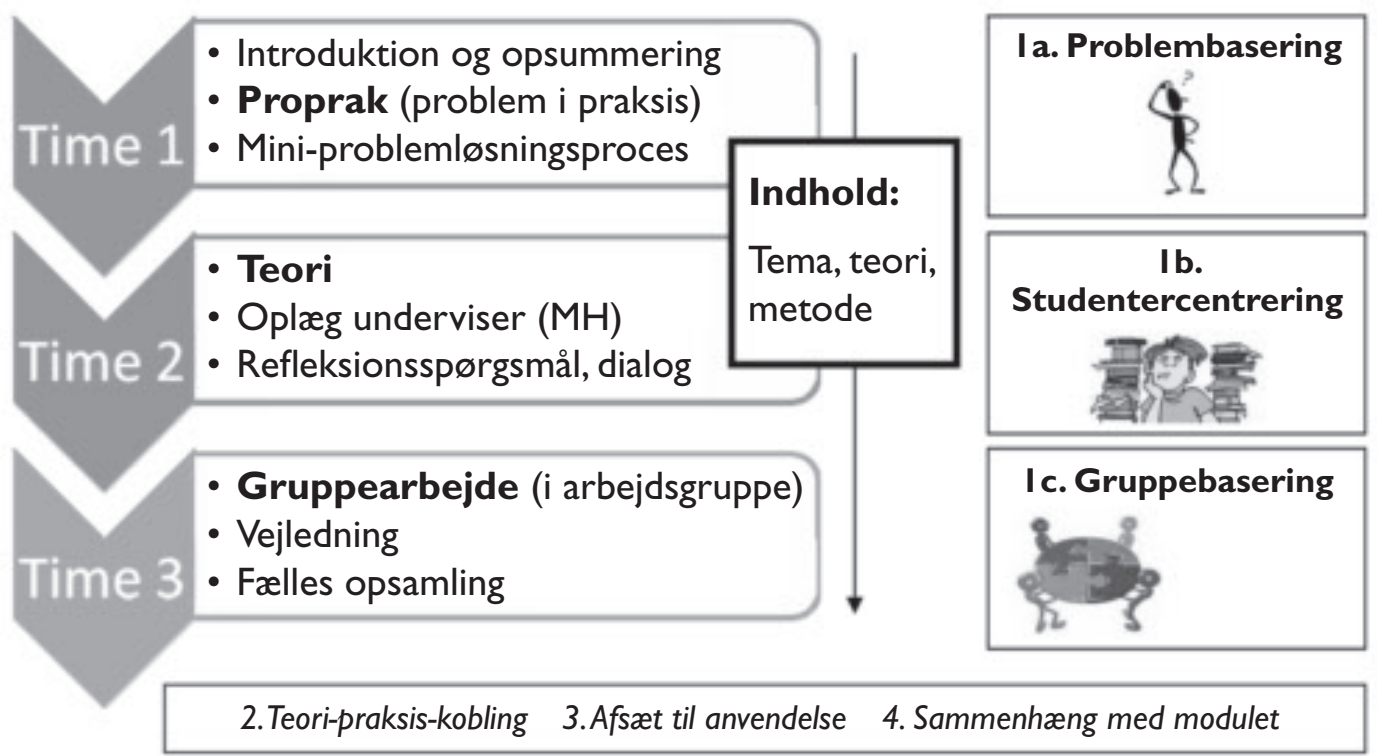

\section{Time 3: Gruppearbejde}

I den tredje time blev alle fire didaktiske principper i undervisningsforløbet sat i spil samtidig, med fokus på gruppebasering, anvendelsesperspektivet og sammenhængen til modulet (se Tabel 2). I denne time arbejdede modulets arbejdsgrupper sammen, hvor konkrete værktøjer relateret til ProPrak og teori blev anvendt, diskuteret og udviklet. Indholdet i Time 3 var således relateret direkte til gruppens ageren i samspillet mellem produkt og proces i modulet - det som Pettersen (2001, s.60ff) betegner ved kriterierne 'effektivitet' og 'moralsk adfærd'.

Arbejdsgrupperne arbejdede i undervisningslokalet eller ved borde i nærheden, således at jeg hurtigt kunne bevæge mig rundt og vejlede alle grupper. ${ }^{9} \mathrm{Jeg}$ kom naturligvis ikke dybdegående ind $\mathrm{i}$ arbejdsgruppernes proces i den enkelte undervisningsgang, men jeg bestræbte mig på at efterleve de centrale vejledningsområder og -opgaver (Pettersen, 2001, s. 104ff). Min vejlederrolle vil jeg betegne som en studenter-afstemt procesvejleder ${ }^{10}$, jævnfør min ageren på baggrund af de studerendes læringsforudsætninger, hele modulets formål og undervisningsforløbets mål og indhold.

Formativ evaluering ${ }^{11}$ indgik som en integreret del af de studerendes læreproces i forløbet, hvilket jeg specifikt koblede til den tredje time af de enkelte undervisningsgange. I løbet af de ni uger skulle arbejdsgrupperne aflevere tre kortfattede dokumenter koblet til konkrete metodiske værktøjer, som jeg integrerede $i$ en feedback-seance den efterfølgende gang. Denne integrerede, formative evaluering var derfor med til at binde de enkelte undervisningsgange sammen og samtidig sætte fokus på opsummering og evaluering (trin 7 i 7-trinsmodellen) i de studerendes læreproces.

De sidste fem minutter af den tredje time blev afsluttet med en fælles opsamling på holdet, hvor jeg svarede på generelle spørgsmål og spurgte ind til de studerendes læring i relation til dagens tema. Mit formål med dette var at binde knude på dagens røde tråd, således at de studerende fik reflekteret over og italesat viden og erfaringer som stimulans til både egen og andres læreproces (jæunfør Gergen, 1994 og Wenger, 2007 - se tidligere).

Sammenhængen mellem de tre timer på baggrund af de didaktiske principper ses på Figur 1: Det problembaserede undervisningsdesign.

\section{Eksempel på timernes sammenhæng}

Dagens tema den femte gang var 'Styring af og vidensdeling i gruppearbejdet' og handlede om, hvordan grupperne kunne effektivisere og udvikle arbejdsprocesserne $\mathrm{i}$ den tid de er sammen - og om forholdet til den tid hvor de arbejder individuelt. I ProPrak'ken var holdet delt i tre grupper med cirka otte studerende i hver. Her skulle gruppen bygge en figur af legoklodser uden brug af verbal kommunikation, hvor alle gruppemedlemmer fik udleveret en specifik oplysning (viden), som skulle integreres i løsningen af opgaven. Blandt andet måtte kun én person røre ved klodserne, hvilket virkelig satte fokus på selve styringen og ledelsen i gruppen.

I teoritimen problematiserede jeg forholdet mellem ledelse af en arbejdsgruppe som henholdsvis en person kontra en funktion med afsæt i rolleteori (eksempelvis Belbin, 1981) over for Kubuskonceptets to ledelsesfunktioner: Grøn leder og rød leder ${ }^{12}$ (Herlau \& Tetzschner, 2006). I det afsluttende gruppearbejde afprøvede arbejdsgrupperne de to funktioner, som var tildelt ved lodtrækning, mens de arbejdede med vidensbrainstorm i forhold til modulets igangværende case (Trin 3 i 7-trinsmodellen, Pettersen, 2001, s.78ff). Afslutningsvis evaluerede og diskuterede gruppen dagens arbejde med udgangspunkt $\mathrm{i}$ de to funktioner, for at træffe et bevidst valg omkring hvorvidt styringen af gruppens fællesmøder fremadrettet skulle være person-, funktionsstyret eller en kombination heraf. 


\section{Fra det problembaserede undervisningsdesign til to generelle budskaber}

I artiklen har jeg givet et operationaliseret bud på et design til et undervisningsforløb, hvor problembaseret læring og metodiske værktøjer udgør det overordnede fagområde (se overblik på Figur 1). De idrætsstuderende på SDU har entydigt tilkendegivet ${ }^{13}$, at undervisningsdesignet med ProPrak, teori og gruppearbejde har motiveret dem til konstant aktiv deltagelse, mens de samtidig har oplevet en høj grad af målopfyldelse. Som sammenligning med andre ikke-kropslige forløb udtrykker de studerende, at netop praksis-teori-koblingen og det at arbejde med et bestemt fagligt indhold på forskellige måder har haft en positiv betydning $\mathrm{i}$ læreprocessen.

Men hvordan kan disse subjektive, om end årgangsgennemgående, udsagn forstås $i$ et mere generelt læringsperspektiv? Ved f.eks. at analysere de studerendes læreproces under den enkelte undervisningsgang ud fra Kolbs (1984) læringscirkel fremkommer det billede, at designet på forskellige tidspunkter stimulerer hver af de fire dimensioner: 'Concrete Experience' (Time 1), 'Reflective Observation' (Fra Time 1 til 2), 'Abstract Conceptualization' (Time 2) og 'Active Experimentaion' (Time 3). Tillige starter ProPrak i det konkrete og håndgribelige, hvilket jeg gennem årene har erfaret passer godt til de idrætsstuderendes læringsforudsætninger (Hiim \& Hippe, 1993) og læringsstile (Kolb, 1984; Lauridsen, 2007). Jeg funderer derfor over, hvad der ville ske, hvis jeg byttede om på de enkelte timer i designet.

Når du som universitetsunderviser udvikler dit undervisningsdesign på baggrund af fagdidaktiske valg, er det ikke en selvfølge at mit problembaserede design passer til din målgruppe og dit forløb. Men jeg håber alligevel, at artiklens to generelle budskaber - her stillet som spørgsmål - vil inspirere dig i dine didaktiske overvejelser og valg omkring udviklingen af god undervisning - og ikke mindst realiseringen af denne i praksis: 1) Hvordan kan dit undervisningsdesign konkret integrere det indhold og de metoder, som de studerende skal stimuleres til lære? og 2) hvordan kan forskelligne fremgangsmåder og organisationsformer anvendes som supplerende indgangsvinkler til et bestemt fagligt indhold?

\section{Referencer}

Belbin, R. M. (1981). Management Teams - Why we succeed or fail (second edition). Oxford, USA: Elsevier Ltd.

Biggs, J. (2003). Teaching for Quality Learning at University (second edition). Berkshire, UK: Open University Press.

Boud, D. (1985). Problem-based Learning in Education for the Professions. Sydney: Higher Education Research and Development Society of Australia.

Dahl, P. N. (2008). "Studenter-afstemt vejledning og kommunikation«. I: Krogh, L. et al. (red), Projektpadagogik - Perspektiver fra Aalborg Universitet, s. 89-104.Aalborg: Aalborg Universitetsforlag.
Gergen, K. J. (1994). Virkelighed og relationer - Tanker om sociale relationer. København: Dansk Psykologisk Forlag (2. udgave på dansk, 2005).

Godden, D. R. \& A. D. Baddeley (1975). "Context-dependent memory in two natural environments: on land and underwater". In British Journal of Psychology, 66:3 (Aug. 1975), p.325-331.

Herlau, H. \& H. Tetzschner (2006). Fra jobtager til jobmager. Frederiksberg: Forlaget Samfundslitteratur.

Hiim, H. \& E. Hippe (1993). Laring gennem oplevelse, forståelse og handling - En studiebog i didaktik. København: Gyldendal, Nordisk Forlag (2. udgave på dansk, 2007).

Hovgaard, M. (2009). Laring $i$ Garing - når kvalifikationer og kompetencer går hånd $i$ hånd. Odense: Specialeafhandling, Institut for Idræt og Biomekanik, Syddansk Universitet.

Illeris, K. (2001). Laring - aktuel laringsteori i spandingsfeltet mellem Piaget, Freud og Marx. Frederiksberg: Roskilde Universitetsforlag.

Kolb, D. A. (1984). Experiental Learning: experience as the source of learning and development. New Jersey: Prestice-Hall.

Kolmos, A. (2008). »PBL og projektarbejde«. I Krogh, L. et al. (red). Projektpadagogik - Perspektiver fra Aalborg Universitet. Aalborg: Aalborg Universitetsforlag, s. 13-26.

Kolmos, A. et al. (2002). „Udvikling af proceskompetencer gennem projektarbejdet - udvikling af et fagområde«. I Kolmos, A. \& Krogh, L. (red.). Projektpadagogik i udvikling. Aalborg: Aalborg Universitetsforlag, s. 201-220.

Laursen, P. Fibæk (1999). Didaktik og kognition - En grundbog. København: Gyldendals lærerbibliotek, Nordisk Forlag.

Lauridsen, O. (2007). Fokus på laring - om lacingsstile $i$ dagligdagen. København: Akademisk Forlag.

Lave, J. \& E. Wenger (1991). Situeret laring. København: Hans Reitzels Forlag (dansk udgave, 2003).

Macdonald, R. (2001).»Problem-Based Learning: Implications for Educational Developers». In: Educational Developments, SEDA, May 2001, p.1-5.

Mennin, S. \& R. Souza (2009). "Essential Skills in Medical Education«. ESME Course, AMEE Conference, Malaga 2009. [Kursusmateriale].

Olsen, P. B. \& K. Pedersen (2003). Problemorienteret projektarbejde en varktojsbog (3. udgave). Frederiksberg: Roskilde Universitetsforlag.

Pettersen, R.C. (2001). Problembaseret laring - for elever, studerende og lacere. Frederikshavn: Dafolo.

Studieordningen (2008). Idræt og Sundhed, Syddansk Universitet, Bacheloruddannelse: http://www.sdu.dk/ /media/Files/Information_til/Studerende_ved_SDU/Din_uddannelse/Idraet/ Studieordninger/Studieordning \%20bachelor.ashx [Link]

Tofteskov, J. (1996). Projektvejledning - og organisering af projektarbejde. Frederiksberg: Samfundslitteratur.

Wenger, E. (2007). "Social læringsteori - aktuelle temaer og udfordringer«. I K. Illeris, (red.). Laringsteorier - Seks aktuelle forståelser. Frederiksberg: Roskilde Universitetsforlag, s.61-79.

\section{Noter}

1 God undervisning: Blandt andet deltageraktivitet og -interaktion, velvalgt indhold og fokus på sammenhængen mellem didaktiske parametre (Biggs 2003, Laursen 1999, Mennin \& Souza 2009 og Hiim \& Hippe 1993).

2 PBL-modeller:Artiklen (Kolmos, 2008), som bygger en tidligere analyse, har netop til formål at sammenligne de to traditioner.

3 Proceskompetencer: Disse er eksplicit i fokus på moduler på 1. og 3. studieår, men er på nuværende tidspunkt ikke et tværgående fagområde (eksempelvis som beskrevet i Kolmos et al., 2002) på uddannelsen.

4 Tre lektioner i træk: Jeg valgte selv denne varighed ud fra modulets timebudget og rammefaktorer.

5 Empiri: Kvalitative og kvantitative evalueringer af PBL-forløbet og hele modulet under den første afvikling i efteråret 2008. Desuden store mængder empiri fra min specialeundersøgelse - 
omhandlende et forløb for studerende med problembaseret projektarbejde og et metodisk funderet undervisningsforløb (Hovgaard, 2009).

6 ProPrak: Under Gang 1 udtrykte mange studerende en naturlig undren over termen og dens betydning. I en skriftlig evaluering (del af Gang 9) over undervisningsforløbet nævnes ProPrak stort set eksplicit af alle studerende i meget positive vendinger.

7 Problemløsningsfaser: I praksis kan faser udelades, prioriteres forskelligt, der kan hoppes tilbage og frem og/eller der kan foregå små cirkulære processer (f.eks. ud fra Kolbs (1984) The Learning Process) under én fase i 7-trinsmodellen.

8 Valg af indhold: Dette er en grundlægende betragtning. Der kan være grunde til at træffe andre didaktiske valg, hvilket i høj grad knytter sig til undervisningens mål.

9 Gruppearbejde og vejledning: På baggrund af empiri og analyser fra min specialeundersøgelse (Hovgaard, 2009) valgte jeg at integrere mødet med de enkelte arbejdsgrupper som en del af undervisningsrammen, således at jeg selv spillede en aktiv rolle $i$ at møde de studerende.

10 Studenter-afstemt procesvejleder: Reference til Tofteskov, 1996, s.21ff; Dahl, 2008 og Olsen \& Pedersen, 2003, s.123ff.

11 Evaluering: Undervisningsforløbet og dettes kompetencemål indgik ikke eksplicit som en del af den afsluttende prøve i modulet.

12 Grøn leder og rød leder (Herlau \& Tetzschner, 2006): Den grønne leder er procesorienteret og sikrer at alle medlemmer er deltagende på mødet; mens den røde leder er produktfokuseret og skriftliggør gruppens beslutninger og opgaver. Gruppemedlemmerne roterer mellem de to funktioner.

13 Tilkendegivelse: I en skriftlig og mundtlig evaluering henvendt personligt til mig, i studiegrupper gennem en faglig tutor (ældre studerende) til modultovholderen og i et elektronisk anonymt evalueringsskema efter modulet. 